\title{
Concubitu Prohibere Vago: Sex and the Idiot Girl, 1846-1913
}

\author{
Ralph Sandland
}

Published online: 10 March 2013

(C) The Author(s) 2013. This article is published with open access at Springerlink.com

\begin{abstract}
This paper interrogates Michel Foucault's claim, that the spread of psychiatric power originated in concerns around the educatability of idiot children in the latter decades of the nineteenth century, before being applied to adult "defectives". It is argued that Foucault, although partially correct, fails adequately to consider the extent to which the base concept, of "instinct", was linked in particular ways to female idiot sexuality. The paper challenges Foucault's view through an analysis of a series of nineteenth century cases involving the rape of female idiots, arguing that their sexuality was understood in terms of a relation to instinct which manifested in terms of an opposition between dangerousness and vulnerability. It then traces that opposition into the Mental Deficiency Act 1913 where, it is argued, it functioned in a collapsed form-now, the vulnerable were dangerous and the dangerous were vulnerable - and in which form it underpinned a psychiatrised regime for the control of mentally defective women through the control of their sexuality.
\end{abstract}

Keywords Abnormality · Foucault · Idiot sexuality · Instinct · Mental Deficiency Act 1913

\section{Introductory Comments}

The influence of Michel Foucault's "histories of the present" (1977, 31) on contemporary understanding of psychiatry, social work and medicine, and much

The phrase "Concubitu Prohibere Vago", which I encountered reading Blackstone's Commentaries, Morrison (2001), Comm. I 438, translates as "to forbid a promiscuous intercourse". It seems to me to capture the issues with which I am concerned in this paper.

R. Sandland $(\bowtie)$

School of Law, University of Nottingham, Nottingham NG7 2RD, UK

e-mail: ralph.sandland@nottingham.ac.uk 
else, particularly human sexuality, has been profound. In a number of texts, Foucault argued consistently that the benign, caring or protective aspects of these "disciplines" merely dissembled their exercise of normative power. However, as has often been noted, Foucault's work lacks any sustained analysis of the gendered dimensions of power. In this article, I seek to add to that body of scholarship which is critical of Foucault in this regard. My focus is on his explanation of the spread of psychiatric power, as a mechanism for the policing of socio-cultural norms, in the decades surrounding the turn of the twentieth century. I will argue that Foucault's failure to consider gender means that he fundamentally misrepresents the path taken by that development.

This claim will proceed by way of an analysis of the nineteenth century legal construction of the "sexuality" of women and girls with what would these days be called "learning disability". It is important to understand both of these terms as discursive artefacts, and as normative injunctions with existential effects. The substantive shape and scope of such terms-what counts as sexual, what indicates learning disability, what constitutes normalcy, what is deviant or abnormal-is not self-evident or inherent. Rather, such things are determined, to some extent at least, by their historical limits. Contemporary knowledge is the product of the historical and on-going interplay of truth claims, power plays and resistance to power, of innovation, subversion and appropriation. The contemporary term, of "learning disability", for example, has been the subject of an intense politics over the last several decades. The consequence of this has been the traditional medical, individualised, model of disability — which sees disability as the problem and as inherent to the individual - has given much ground to a "social" model of disability which, by contrast, "sustains a focus on stigma and exclusion" (McRuer 2011: 112). Such models understand "disability", as a lived reality, to be a consequence of the way in which normative social, economic, and other structures, consciously or otherwise, have exclusionary effects.

Some reject the term "disability" in favour of "disablement" (Oliver and Barnes 2012), seeking in so doing to address two concerns. First, that the concept of disability shares a common assumption with terms that have fallen out of professional usage: terms such as "retarded", "defective", "idiot" and "imbecile", in that all are pejorative or victim-blaming. Second, such terms are also seen as constructive: the life experiences of those so labelled are mediated through the discursive frame of the label as a social reality. At the start of the period in which I am interested, the orthodox term, as had been the case for many centuries, was "idiot", ${ }^{1}$ but this term lacked precision, and was used interchangeably with the equally ancient term "imbecile". It functioned as little more than a label, with very little if any formal substantive content. Certainly, medical professionals had very little interest in idiots. Similarly, law had very little to say about idiocy, other than recognising that idiots existed, and providing, irregularly, for the management of

\footnotetext{
1 Many terms had been in usage at one time or another, including "natural fool", "changling" and "innocent", but by the nineteenth century "idiot" and "imbecile" were predominant: see Wright (1996).
} 
their affairs (Unsworth 1993). This was to change with a series of rape cases, beginning in 1846. Thereafter, the law had increasingly more to say about idiocy, and it articulated its discourse through the vehicle of the sexuality of female idiots. In a sense, this paper is a study of the development of meanings for existent, but vacuous, labels, and the construction of new ones, by law and by discourses articulated in other fields-psychiatry, evolutionary biology and eugenics, social policy - in ways which were to significantly affect the life experiences of significant numbers of women well into the twentieth century. For there can be no starker example of the point that the categories which are developed to name and identify intellectual impairment inform the experiential, the material embodiment of the individual, than when the consequence of the identification, or diagnosis, of that individual as a member of the category in question is her, sometimes lifetime, incarceration in an idiot asylum.

My analysis covers the period beginning with the legal construction of the sexuality of female idiots in these cases, and traces the husbanding of that construction through to the Liberal Government's Mental Deficiency Act of 1913, during which period idiocy was both refined and expanded in meaning, maturing eventually into the much broader concept of "mental defective". This was not merely a shift in terminology, but constituted a significant expansion in the target population. In 1820, the asylum doctor, J.E.D. Esquirol (who, as will be seen below, has a crucial role in the history of idiocy, and whose work had set in train the series of events which led, amongst many other destinations, to the $1913 \mathrm{Act}$ ), noted that "idiocy is a rare phenomenon among us; since, out of 7,950 insane persons of both sexes, there are only 203 idiots" $(1845,479)$. Esquirol was referring only to those detained in an asylum in Paris, and no doubt many idiots were housed elsewhere. Nonetheless, by the time of the 1913 Act, "rare phenomenon" could clearly not be used to describe the 133,000 "feeble-minded" citizens revealed by the 1901 National Census (Thomson 1998, 21): and the "feeble-minded" were only one of the target groups of the 1913 Act.

The 1913 Act was intended to provide a long-term solution to the "problem" of the sexuality of "mental defectives", defined to embrace both idiots and imbeciles, along with two newer categories of defective person, namely the "feeble-minded" and "moral imbeciles". ${ }^{2}$ Although guardianship was an option under the new regime, ${ }^{3}$ the Act is mainly remembered for its implementation a policy of segregation and institutionalisation for those (vulnerable and/or dangerous) mentally defective adults who were unable to care for themselves, or for whom care was not otherwise available. By 1939, almost 100,000 individuals were under some form of control imposed by the 1913 Act (Thomson 1998, 2), many more having passed through the system in the intervening years. From the start, the use of the 1913 Act to control mentally defective women through controlling their sexuality was conspicuous (Walmsley 2000).

\footnotetext{
${ }^{2}$ S 1(a)-(d), Mental Deficiency Act 1913.

${ }^{3}$ S 2(1), Mental Deficiency Act 1913.
} 
The history that I will chart shares a narrative thread with Foucault's analysis of the development of psychiatry by emphasising the fundamental importance thereto of the concept of instinct. I agree with Foucault that

Basing itself on the instincts, nineteenth century psychiatry is able to bring into the ambit of illness and mental illness... all the serious disorders and little irregularities of conduct that are not, strictly speaking, due to madness. On the basis of the instincts and around what was previously the problem of madness, it becomes possible to organize the whole problematic of the abnormal at the level of the most elementary and everyday conduct... In this way instinct becomes the major theme of psychiatry and occupies an increasingly prominent place (Foucault 2003a, 132).

My disagreement with Foucault concerns the mechanism through which this shift from illness to abnormality is achieved. For Foucault it is the idiot child: psychiatric power is first nurtured and diffused through the conflation of medical and pedagogical discourses, practices and institutions, aimed to facilitate the intellectual development of those who could not achieve it within the nascent mainstream education system, and to provide for those incapable of development. Only then does it extend its reach also to embrace the control of adult idiots. ${ }^{4}$ As will be seen, legislative developments from the passage of the Idiots Act 1886 to that of the Mental Deficiency Act 1913 do indeed follow the path from child to adult that Foucault describes. However, by 1886, the equation of female idiot sexuality with instinct had already been established, and it was perceived problems associated with a failure to control mentally defective female sexuality, and hence the production of defective offspring, that in large measure animated the 1913 Act.

In developing this argument, I will first consider the emergence of instinct theory in relation to idiocy and sketch its subsequent entry into legislation, starting in 1886, demonstrating that if one begins legal analysis with the Idiots Act, Foucault's analysis seems vindicated. I shall then turn to the Victorian caselaw, in order to show, contra Foucault, that, in England at least, the psychiatric power applied to the idiot child and later to the mentally defective adult was, indeed, always already gendered. Moreover, the gendering of instinct was achieved by reading the operation of instinct through a problematic opposition between vulnerability and dangerousness. Finally, I shall demonstrate that the 1913 Act, although discussed in the literature principally in terms of whether or to what extent its provisions reflected the new science of "eugenics" (Schenk and Parles 1968, 144; Frieden 1979, 658; Farrall 1985, 244; Kelves 1985, 99), is in fact best seen as the generalisation of the theory of instinctive female idiot sexuality which had been developed in the caselaw beginning in 1846 .

\footnotetext{
4 Thereafter, for Foucault (although the claim is highly debatable), through the work of Freud, this normative power extends further still, into the "normal" (non-idiot) population. This for Foucault is what makes the early controls over the idiot child so significant. My concerns here, however, are focussed more narrowly, on the treatment of intellectually impaired persons.
} 


\section{Idiocy and Instinct in Psychiatric Theory}

Section 341 of the Lunacy Act 1890 provided that "'lunatic' means an idiot or person of unsound mind". In so doing, it followed earlier legislation, ${ }^{5}$ implementing the orthodox view, that "lunacy" was an umbrella category, and idiocy was a species of lunacy. By 1890 this view was, however, increasingly outmoded. As the nineteenth century progressed, "It became clear that the insane had been inaccurately grouped together into a homogeneous body whereas at least two categories could be identified: [the] clearly insane... and those who suffered from a lack of intellectual power" (Bartley 1999, 121). The key development came in 1820, when the noted French proto-psychiatrist J.E.D. Esquirol $(1845,446)$ argued that earlier authors had wrongly "constituted it [idiocy] a variety of insanity". For Esquirol (1845, 446), by contrast

Idiocy is not a disease, but a condition in which the intellectual faculties are never manifested; or have never been developed sufficiently to enable the idiot to acquire such an amount of knowledge, as persons of his own age, and placed in similar circumstances with himself, are capable of receiving...We can conceive of no possibility of changing this state. Nothing teaches us how to impart, for a few moments even, to the wretched idiot, an increase of reason or intelligence.

With Esquirol, then, began the distillation of the two concepts-of lunacy and idiocy, illness and disability - that was eventually to gain legal orthodoxy in the Act of 1913.

As well as distinguishing idiocy from lunacy, Esquirol also insisted on a distinction between imbecility and idiocy. He divided the former into two categories and the latter into three. Imbeciles have some intellectual capacity, indicated by their level of articulacy: "In the first degree of imbecility, speech is free and easy. In the second, it is less easy, and the vocabulary is more circumscribed" $(1845,470)$. As far as idiots are concerned, "In the first degree of idiocy, properly so called, the idiot uses merely words and short phrases. Idiots of the second degree, articulate only monosyllables, or certain cries" $(1845,470)$. Idiots of the third, and lowest, degree are not merely intellectually subhuman: "They are below the brute; for animals possess the instinct for self-preservation and reproduction. Idiots do not possess this instinct, and have no sense of their existence" $(1845,467)$. Idiots of the first and second degree, by contrast, "have a very small number of limited ideas, beside their passions for the supply of instinctive wants... Reason does not control their actions; which are few, and repeated, either from habit or the force of imitation" (1845, 448). Later, he explains again that idiots have "merely the rudiments of intelligence, and instinct controls all the faculties" $(1845,454)$.

Esquirol's explanation of idiocy differed radically from those of earlier theorists of lunacy such as Pinel. Theirs was an understanding-of lunacy, and of idiocy as a species of lunacy- "conceived in terms of error, illusion, delirium, false belief, and non-obedience to the truth" in which "there was no place within psychiatric

\footnotetext{
5 S 114, Lunacy Act 1845, s 84, County Asylums Act 1845.
} 
discourse for instinct as a brute, dynamic element" (Foucault 2003a, 130). For Foucault, the emergence of "instinct" as an explanatory concept marks the point at which modern psychiatry-understood as a general mechanism of power, organised around the articulation a system of norms, applied to the "abnormal", rather than a set of treatments, practices and strategies applied to the insane-begins to appear.

One further development was, however, necessary for this to occur. As seen above, Esquirol could "conceive of no possibility of changing this state" and hence he removed idiocy, as untreatable, from the domain of psychiatric intervention. Esquirol's view was challenged by Edouard Séguin's (1842, 1846) influential argument that some idiot children, if not "curable", were nevertheless "improvable". Séguin's work to some extent encapsulated ideas which were already in circulation. In England, the first dedicated asylum for idiots, the National Idiots Asylum, opened in $1847,{ }^{6}$ followed by four others over the next two decades. ${ }^{7}$ This did not constitute the start of a policy of mass institutionalisation, however. These institutions charged for their services and "catered largely for children and adults from the emerging middle classes" (Jackson, 2000, 23). Institutions catering for pauper idiots began to appear in the 1870 s, but even by 1881 , it was estimated that a mere $3 \%$ of the 29,542 idiots accommodated in some sort of institution were to be found in the idiot asylums, the vast majority being in workhouses, lunatic asylums or prisons (Gladstone 1996, 110). Nonetheless, the importance of Séguin's contribution is that it restored the rationale for intervention that Esquirol had seemed to undermine.

\section{The Psychiatrisation of the "Idiot Child"}

Foucault argues that in viewing the "idiot child" as amenable to education/ treatment, psychiatry commences the construction of a "profoundly new category", of "abnormality" as opposed to "illness". For him, "the confiscation of this new category by medicine, its psychiatrization, was precisely the principle on which the diffusion of psychiatric power was based" (2003a, 211). In short, for Foucault (2003b, 221)

Through the practical problems raised by the idiot child you can see psychiatry becoming something infinitely more general and dangerous than the power that controls and corrects madness: it is becoming power over the abnormal, the power to define, control, and correct what is abnormal.

Developments in England seem to corroborate Foucault's view. Practical problems were thrown up by the Elementary Education Act 1870, which introduced universal elementary education for all children aged five to thirteen. ${ }^{8}$ Its implementation

\footnotetext{
${ }^{6}$ Initially located in London, the asylum moved to Earlswood in Surrey in the 1850s, where it had capacity for 500 inmates.

7 The Eastern Counties Asylum was established at Colchester in 1959, the Western Counties Asylum at Exeter and the Northern Counties Asylum at Lancaster in 1864, and the Midlands Counties Asylum at Knowle, Staffordshire in 1868 (Gladstone 1996, 137).

8 Ss 4, 74, Elementary Education Act 1870.
} 
revealed large numbers of children said by their teachers to be unable to benefit from this by reason of being an idiot or an imbecile. By 1885, concerns were such that a Royal Commission was established, which promptly confirmed, long before its final Report (1889), that there was a problem of considerable magnitude (Simmons 1978, 388).

The ensuing Idiots Act of 1886 encouraged local authorities to provide alternative "care, education and training" 9 for such children, in a hospital, institution, or licensed house. A child had to be certified by a "duly qualified medical practitioner" 10 as "an idiot or imbecile, capable of receiving benefit" from being placed in the accommodation in question, and the responsible officer of the receiving institution had to certify that the child so admitted "is alleged to be capable of deriving benefit from the treatment he [or she] will receive herein". ${ }^{11}$ At the time, the impact of the Act was judged as minimal. This was largely because it bestowed powers, but did not impose duties, on local authorities to act, and offered insufficient financial incentive for them to do so (Thomson 1998, 12; Jones 1972, 185). Increasingly, however, it was also claimed that the 1886 Act had been drawn too narrowly. In particular, "feeble-minded" children presented similar problems to educators, but were outside the scope of the 1886 Act.

The law had long recognised idiots and imbeciles, but the concept of "feeblemindedness" was new in the late nineteenth century. It has been said (first by Bosanquet 1914; later by Simmons 1978, 388), albeit incorrectly, ${ }^{12}$ that the term "feeble-minded" was first coined in 1876 by Sir Charles Trevelyan, a prominent member of the philanthropic campaigning and service-providing Charity Organisation Society (COS). ${ }^{13}$ Nonetheless, Trevelyan certainly captured the spirit of the age with his usage of the term. His purpose was to distinguish the feeble-minded from idiots, on the basis that whilst idiots were incapable of improvement, this was not the case with the feeble-minded child. Although this distinction did take hold, and indeed, concerns about the feeble-minded grew steadily over the following decades, the feeble-minded were nonetheless seen as close to idiots and imbeciles, the difference being merely one of degree, in both in legal terms and in terms of public understanding. As Foucault $(2003 \mathrm{~b}, 208)$ noted, although there are two pathologies - a pathology of lack of development and a pathology of underdevelopment-they were understood as complementary, with "one being the final effect of the other".

Some local authorities were so concerned about the problem of feeble-minded children that they opened "special schools" for such children without waiting for legislation and "By 1897, there were 1,300 children receiving education in thirtyone special schools" (Thomson 1998, 15). However, special schools entailed special

\footnotetext{
9 S 4, Idiots Act 1886.

${ }^{10} \mathrm{~S} 4$, Idiots Act 1886.

${ }^{11} \mathrm{~S} 9$ and Sched, form 3, Idiots Act 1886.

12 Texts, highly influenced by Séguin's work, had been published by Brady (1865) and Duncan and Millard (1866), which linked the "feeble-minded" with, but differentiated them from, idiots.

13 The COS, an influential pressure group, was established in 1868. It campaigned vigorously for legislation to care for the feeble-minded.
} 
costs and local authorities campaigned for legislation on this basis. This pressure coincided with an orchestrated campaign backed by the COS, which commissioned research in the early 1890s (COS 1893) that demonstrated the under-provision for feeble-minded children (and adults) nationally. Various other bodies and individuals argued strongly and consistently for law to address the problem of the feebleminded. Prominent amongst these were persons such as Mary Denby, ${ }^{14}$ a founder of the Lancashire and Cheshire Society for the Permanent Care of the Feeble-Minded in 1898, which existed solely to provide and campaign for institutional care for the feeble-minded. The COS founded the National Association for Promoting the Welfare of the Feeble-Minded (NAPWFM) in 1896 to campaign for legislation, and, when the Poor Law Schools Committee added its voice to the clamour, the result was establishment of the Departmental Committee on Defective and Epileptic Children (1898). Its report was soon followed by the Elementary Education (Defective and Epileptic Children) Act 1899.

The 1899 Act, like the 1886 Act, was permissive, and it too was unevenly implemented as a result. Section 2(1) authorised local authorities to establish dedicated schools or special classes for defective or epileptic children (Copeland 1996). Section 1(1)(b) defined defective children as those who

not being imbecile, and not being dull or backward, are defective, that is to say... children [who] by reason of mental or physical defect are incapable of receiving proper benefit from the instruction in the ordinary public elementary schools, but are not incapable by reason of such defect of receiving benefit from instruction in such special classes or schools as are mentioned in this Act.

At this point, then, "defective" applied to both mental and physical defects, and the Act does not explicitly name this third category of mentally defective children, being neither imbeciles (nor by implication, idiots) on the one hand, nor being within the range of the normal, albeit "dull or backward", on the other. It is, however, clear that what is being referred to here is the "feeble-minded" child, although the law did not yet venture positively to define the term: that would come later, with the Mental Deficiency Act of 1913.

The Acts of 1886 and 1899, taken together, firstly, constructed the tripartite typology of mental deficiency-embracing idiocy, imbecility and feeble-mindedness - which marked a massive extension in the base category of idiocy, and formed the conceptual basis of the 1913 Act, ${ }^{15}$ notwithstanding the copious evidence given to the Royal Commission, set up in 1904 to report on the problem of the feebleminded, about the difficulty of allocating a specific individual to one or other of the categories (Simmons 1978, 391-392). Secondly, these Acts operationalised a process whereby idiocy, imbecility and feeble-mindedness were transformed, from a private problem to be coped with by the families of the defective person, to a

\footnotetext{
${ }^{14}$ Denby was a well-known and influential campaigner for the provision of institutional care for the feeble-minded. For a detailed discussion of her contribution, see Jackson (2000, ch 4).

15 The fourth sub-category of mental deficiency, "moral imbecility", did not involve lack of intellectual, but only moral, development, and was the forerunner of what became psychopathy, seen as distinct from both mental impairment and mental illness. Its route into the 1913 Act differs from that taken by the other three categories of mental deficiency, and it is not considered further here.
} 
social and economic problem, demanding ever-greater intervention by the state. Thirdly, they established a dual measurement of mental deficiency or abnormality: deficiency as the radical absence of intellectual development (idiocy) and deficiency as slow or retarded development (imbecility and feeble-mindedness), and hence mark a switch-point in psychiatric focus, from illness to abnormality, as now the reference point for diagnosis was the "normal" rather than the "healthy". Fourthly, they did so in the context of a rapidly fusing pedagogico-medical discourse. As Potts $(1983,181)$ has noted, "Doctors'...categories became the non-educational basis for educational legislation and provision; they assessed the children referred for separate schooling; they inspected the special schools; they frequently dictated the curriculum, time-tabling and teaching methods". Slippage between the educational and the medical can be seen on the face of the 1886 Act, which, first, identifies a need for "care, education and training", but then responds to that identified need by placing a duty on institutions accepting idiot children to provide "treatment", and to ensure that a doctor "shall reside therein" for this purpose. ${ }^{16}$ Fifthly, this new medical-pedagogical discourse was further fused with a moral discourse: Mary Denby $(1901,1)$, for example, described her interventions and efforts on behalf of the feeble-minded as the application of "scientific morality". Finally, these Acts signalled a preference for segregation and an institutional response.

All of these themes were to feature in the 1913 Act. Hence, it can be seen that there is a clear shift, from child to adult, which marked the spread of psychiatric power as a mechanism to police abnormality, as Foucault suggests. However, as I will now demonstrate, the idiot child was not, in fact, the point of entry into law for instinct theory and the accompanying opposition between vulnerability and dangerousness. That had begun forty years before the Idiots Act, in the case of $R$ $v$ Ryan (1846), ${ }^{17}$ involving an allegation of the rape of an idiot girl. It is from its origins in this case that one can trace an alternative trajectory for the history of instinct and idiocy. Here, the shift is not so much from child to adult, nor from idiot to mental defective, but from isolated legal engagements with individual female idiots and their sexuality, to systematic engagement with the sexuality of mentally defective women as a class, and as a socio-political problem.

\section{6-1885: The Sexuality of Female Idiots and the Emergence of Instinct Theory in Law}

The caselaw starts opaquely, with displacement, with the imputation of a certain set of Victorian values onto the body of a young woman who, being an idiot, cannot share them. And yet, as we shall see, the image of decency and chastity, which the court ascribes to the young woman in this case, carries the possibility of things being other. The idiot, and her sexuality, is always beyond reason and always beyond the human. In time, in later cases, this place will be given a name: "animal

\footnotetext{
${ }^{16} \mathrm{~S}$ 14, Idiots Act 1886.

17 II Cox C.C. (1846-1848) 115.
} 
instinct". But here, in Ryan, a first instance decision of the Central Criminal Court, this otherness exists as the unsaid or the yet-to-be-said; alluded to but, as yet, also obscure.

Although the law report is brief, this case is nonetheless highly significant, when contrasted with the approach taken subsequently. Ryan was indicted for the rape of a female idiot who lacked capacity to act as a witness. The judge, Platt B., in lieu of the availability of her own testimony, "interrogated her father as to her general habits, whether they were those of decency and propriety, and an answer in the affirmative was returned". Nonetheless, despite her undisputed idiocy, and her being "not in a condition to understand right from wrong", Platt B. put the issue of her consent to sexual intercourse to the jury. He said:

The question is, did the connection take place with her consent? It seems that she was in a condition incapable of judging, and it is important to consider whether a young person, in such a state of incapacity, was likely to consent to the embraces of this man; because if her habits, however irresponsible she might be, were loose and indecent, there might be a probability of such consent being given...But here the presumption is, that the young woman would not have consented

Although the jury found Ryan guilty, to twenty-first century eyes, this direction seems clearly contradictory: how there could be the possibility, even the "probability", that consent had been given by a person who was "in a condition incapable of judging", unable to understand questions put to her or the difference between right and wrong? Surely, a young woman found to be "in a state of incapacity" could not, for that reason, have given a valid consent to sexual relations?

The answer lies in appreciating that Platt B. is talking in somewhat coded language when he refers to "her habits", which if, "however irresponsible ${ }^{18}$ she might be, were loose and indecent" would suggest that consent was a "probability". Although the court in Ryan does not name it, it is the concept of "instinct" that unties the apparent contradiction in Platt B.'s summing up. The court accepts that the young woman in Ryan, being an idiot, could never have given a conscious, reasoned, consent to sexual intercourse. But that did not exclude the possibility that she could, and, if she had been "loose and indecent", most probably would, have "consented" to sexual intercourse on some "habitual", that is, "instinctive" level. As can be seen, the future presence of "instinctive consent", and the corollary construction of idiots - at least of some idiots - as animalistic, before and beyond civilisation, hangs over this case like a premonition. But at this time, there was no medico-legal (as opposed to common sense) discourse available through which to articulate it.

A little over a decade later however, in $R v$ Richard Fletcher (1859), ${ }^{19}$ such a discourse is now in evidence. The Court of Criminal Appeal confirmed the conviction of Fletcher for the rape of Jane Jones, a girl of thirteen, ${ }^{20}$ found to be of

\footnotetext{
18 "Irresponsible" here should be taken to mean "lacking in capacity".

19 VIII Cox C.C. 131.

20 The age of consent at common law was twelve. This was put on a statutory basis by the Offences against the Person Act 1861, before being raised to 13 in 1875 and 16 in 1885 .
} 
"weak intellect", "incapable of distinguishing right from wrong", and lacking in the capacity required to act as a witness. ${ }^{21}$ The evidence showed that Jane, who did not usually leave her home unaccompanied, as she was unable to find her way back, did, unusually, do so on the day in question. She met Fletcher and sexual intercourse took place, purportedly with no resistance offered by Jane, although she did protest that Fletcher hurt her, and made to run away when the act was over. Fletcher was convicted following a direction by Hill J., the trial judge, that he should be found guilty if either he had carnal knowledge of Jane (1) by force ${ }^{22}$ and against her will, or (2) by force and without her consent, if the jury was of the opinion that she was incapable of giving consent. ${ }^{23}$ The jury convicted on the basis of the second of these options.

Hill J. recorded that verdict, but postponed sentencing and referred the case to the Court of Criminal Appeal. Before that court, it was argued on behalf of Fletcher that the conviction should be quashed because the law was said to require that the sexual intercourse had been against the will of the complainant. This argument was rejected. The court, citing Ryan, held that the test was "without her consent" rather than "against her will". The main significance of Fletcher, however, lies not with the outcome but with judicial interjections into counsels' pleading of the case. Counsel for Fletcher had submitted that the issue was one of "will", not "consent". Counsel for the Crown had responded by way of referring to the facts and summing up of Ryan, at which point Willes J. intervened, commenting that

There was before me a case of the kind, where the girl was an idiot, tried before me at the Old Bailey. I told the jury that, if she had been ravished without her consent, it was rape; but that if she gave her consent, though from an animal instinct, that would prevent the crime of rape from being committed. There was evidence of a medical man that the girl had animal instincts of a strong tendency. ${ }^{24}$

Lord Campbell then also intervened, to state that "That direction was in accordance with Camplin's ${ }^{25}$ and Ryan's cases. But in this case there was no evidence of that kind, rather to the contrary". ${ }^{26}$

This, then, is the moment when the concept of animal instincts makes it first appearance in the law reports. We are not told, in Fletcher, the name or date of the case to which Willes $\mathrm{J}$. referred, but it seems highly likely that it is $R v \mathrm{Jacob}$ Israel, ${ }^{27}$ heard on 5 January 1857 by Willes J. at the Old Bailey. Israel was charged

\footnotetext{
${ }^{21}$ Supra $\mathrm{n} 20$ at 132.

${ }^{22}$ Force (or fraud) was part of the requirement of the actus reus at the time.

23 Supra $\mathrm{n} 20$ at 132.

24 Ibid at 134.

25 v Camplin (1845) I Cox C.C. 220.

26 Supra n 20 at 134.

27 Proceedings of the Old Bailey, third session, 1856-57, 259, available at Old Bailey Proceedings Online (www.oldbaileyonline.org, version 6.0, 12 June 2011), January 1857, trial of JACOB ISRAEL (t18570105-218) http://www.oldbaileyonline.org/browse.jsp?id=t18570105-218-offence-1\&div=t18570105218\&terms=idiot\#highlight. Accessed 27 November 2012.
} 
and indicted for the rape of his 17 year-old cousin, Julia Cohen. Some months after the alleged offence had taken place, Julia had been examined by Dr Winslow, a well-known alienist, and two other unnamed doctors, who unanimously declared her "perfectly imbecile". ${ }^{28}$ Counsel for Israel argued that there was no case to answer, as there was no evidence of lack of consent, but Willes J. put the matter to the jury. Although there is no specific confirmation to be found in the brief report of the case, the jury must have thought it at least possible that Julia had "consented" because of her "animal instincts of a strong tendency", because Israel was found not guilty.

In 1866, the Court of Criminal Appeal heard a second case involving a defendant named Fletcher: $R v$ Charles Fletcher (1866). ${ }^{29}$ Fletcher was tried for the rape of a 16 year-old idiot girl, Fanny Churchill. He did not deny that intercourse had occurred, but claimed that Fanny had consented to it. There was evidence from a "medical man" that Fanny "Although only sixteen years old...was a fully developed woman; and that strong animal instincts might exist, notwithstanding her imbecile condition". ${ }^{30}$ It was also not clear whether Fanny had previously been a virgin, although the doctor "rather inclined" to the view that she had not. The judge, Keating J., based his summing up on the dicta of Willes J. in the earlier Fletcher case. The jury convicted, but Keating J., clearly uncomfortable with that, reserved the case as there was "no evidence against the prisoner, except the fact of connection and the imbecile state of the girl". ${ }^{31}$ The Court of Criminal Appeal quashed Fletcher's conviction. Giving judgement, ${ }^{32}$ Pollock C.B. held that "we are all of the opinion that some evidence of that allegation [of rape] as a fact ought to be given before a conviction can be obtained". ${ }^{33}$ No doubt, suspicions that Fanny was not a virgin before this incident inclined the court to this view, increasing the likelihood that animal instincts had been operative in her encounter with Fletcher.

The defendant in $R v$ Pressy $(1867)^{34}$ was not so fortunate. Pressy admitted to having sexual intercourse with Charlotte Scovell. ${ }^{35}$ Although "No medical evidence was called...it was apparent that the prosecutrix was an idiot". ${ }^{36}$ Nonetheless, unlike the earlier complainants, Charlotte was able to give evidence. She stated in court that "He put his thing in me-that's wrong. He hurt me". ${ }^{37}$ Under crossexamination, she further explained that "I knew it was wrong at the time. I did not do anything to him. I don't like to hurt nobody". ${ }^{38}$ Charlotte's mother and father, and a police officer, all gave evidence that Pressy had confessed that to them he had

\footnotetext{
28 At this time, the terms "idiot" and "imbecile" were used interchangeably.

29 X Cox C.C. (1864-1867) 248.

${ }^{30}$ Ibid at 248.

31 Ibid at 249.

32 On behalf of a court of five.

33 Supra n 29 at 249.

34 XI Cox C.C. (1868-1870) 635.

35 We are not told Charlotte's age.

36 Ibid at 636.

37 Ibid at 635 .

38 Ibid at 635.
} 
raped Charlotte. ${ }^{39}$ Pressy was found guilty by a jury, and the Court of Criminal Appeal decided that the conviction ought not to be disturbed. ${ }^{40}$ This case bucks the trend: Charlotte clearly had greater mental capacity than the prosecutrixes in the earlier cases, and her evidence amounted to a statement that she had not given consent. That Keating J. thought it necessary to seek the affirmation of the Court of Criminal Appeal as to whether he ought to have put the case to the jury does, however, indicate the absent presence of animal instincts, even here in this fairly straightforward case, for what other reason would Keating J. have had to seek such affirmation but this?

In $R v$ Robert Barratt (1873), ${ }^{41}$ the last in this line of cases, Barratt was found guilty of the attempted rape of Mary Redman, aged 14. Mary was brought into court but was unable to give evidence, being "evidently idiotic" ${ }^{42}$ : she was blind and "hardly capable of understanding anything that was said to her". ${ }^{43}$ She "could not communicate to her friends what she wanted", although "if told to lie down she would do so". ${ }^{44}$ On the day in question, Mary had been placed by her sister on a couch. Barratt, a friend of the family and visiting at the time, then sent Mary's sister on an errand, leaving him alone with Mary. Mary's father later approached the house and, looking through the window, testified that he saw Barratt lying on top of Mary. By the time he entered the room, Barratt had stood up and was buttoning up his trousers. Mary was "lying quietly on the couch". ${ }^{45}$ However, "Beyond this there was no evidence to show under what circumstances the prisoner had or attempted to have connection with the girl". Medical evidence was that there were no signs of violence, but "there had been recent connection, and he [the doctor] thought she had been in the habit of having connection". ${ }^{46}$ Counsel for the defendant argued that there was evidence neither of penetration, nor of lack of consent or will.

Honyman J., the trial judge, referring to the direction of Willes J. in the first Fletcher case, put the question of rape to the jury, and Barratt was convicted of attempted rape. Sentencing was postponed, however, because Honyman J. had decided to reserve for the Court of Criminal Appeal the question of whether there was sufficient evidence for the case to have gone to the jury. The appeal court upheld the conviction, there being no evidence that Mary had given consent; indeed "the poor creature was not capable of giving consent". "Here, in distinction to the second Fletcher decision, the evidence of "prior connection" was seemingly taken as evidence that Mary had been abused in the past, rather than of the presence of animal instincts to engage in sexual activity.

\footnotetext{
39 Ibid at 635-636.

${ }^{40}$ Kelly C.B. was the only member of the Court of Criminal Appeal to give a (very brief) judgement. No counsel appeared for either side.

41 XII Cox C.C. (1871-1874) 498.

42 Ibid at 499.

43 Ibid at 498.

44 Ibid.

45 Ibid at 499.

46 Ibid at 498.

47 Ibid at 500 (Kelly C.B.).
} 
Honyman J. referred the Court of Criminal Appeal to the two Fletcher cases. Counsel for the Crown (Barratt was not represented) informed the appeal court that at trial "it was supposed that the two cases of Reg. $v$ Fletcher were adverse to one another and that the first was overruled by the second" but, he argued, "this is not so". ${ }^{48}$ Rather, they should be seen as compatible: in the first case, Jane Jones lacked capacity to consent, and there was no evidence of the presence of "animal instinct"; whereas in the second, although Fanny Churchill also lacked capacity to give a reasoned consent, there was at least the possibility that animal instinct had been present, hence the quashing of Fletcher's conviction.

The court unanimously agreed with this submission. As such, Barratt provides yet another endorsement of the "animal instincts" thesis, and its antithesis, the "innocent idiot". By now, the radical opposition between the two, as can be seen, was firmly embedded in the common law and functioned always as the mechanism through which the sexuality of female idiots was analysed in any given case. Many commentators have noted (see for example Doyle 2010, 113; Craft 1983; McCarthy 1999 , ch 2) that idiocy at a general level was constructed in terms of an opposition between vulnerability and danger, and as these cases demonstrate, the same was true of idiot sexuality. More specifically, the sexuality of female idiots was understood in terms of the relation of idiocy to instinct, as mediated through this opposition.

The use in these cases of the concept of "instinct" by those offering medical evidence, and its ready acceptance by the judiciary, constitutes an important achievement for Esquirol's understanding of idiocy. Indeed, although apparently more by luck than judgement, given the very imprecise use of the terms by those giving evidence in the caselaw, its compatibility with Esquirol's scheme of idiocy and imbecility is striking. The prosecutrixes in Ryan, the first Fletcher case, and Barratt, seem to have been judged to be idiots of the third degree, below even the level of instinctive consent; whereas the acquittal in Israel and the successful appeal in the second Fletcher case suggest that the prosecutrix in each case was a higher grade, first or second degree, idiot, and thus motivated by animal instinct. Charlotte Scovell, the prosecutrix in Pressy, was, in Esquirol's terms, not an idiot at all but an imbecile (and may well have been classified, rather, as feeble-minded, if that term had been in common use at that time), and the evidence showed that her instincts were held in check by her ability to understand the difference between right and wrong; that is, to internalise the moral codes devised by civilised society for the suppression of the instincts.

This ignominious chapter in the history of the common law was brought to a close by section 5(2) of the Criminal Law Amendment Act 1885. This provided that it shall be an offence for any person who

unlawfully and carnally knows, or attempts to have unlawful carnal knowledge of any female idiot or imbecile woman or girl, under circumstances which do not amount to rape, but which prove that the offender knew at the time of the commission of the offence that the woman or girl was an idiot or imbecile.

${ }^{48}$ Ibid at 499. 
In their commentary on the 1885 Act, Mead and Bodkin $(1885,49)$ explain that "This sub-section was designed to meet a defect in the law", citing the Fletcher case from 1866. This was not the end of cases involving the rape or other sexual abuse of idiot women or girls, but after 1885, in cases where capacity was an issue, prosecutors could charge with the offence under section 5(2) and so it was no longer pertinent to raise a defence grounded in the "animal instinct".

It is crucial to emphasise, however, that the 1885 Act was not seen at the time as a rejection of the idea of instinctive consent in and of itself. Rather, its aim was to ensure that the law did not permit those morally culpable men who had taken sexual advantage of the vulnerability or animalism of idiot women or girls to escape punishment in the criminal courts. This is apparent from the fact that Mead and Bodkin include a lengthy extract from a leading text of the day, Taylor's Medical Jurisprudence. In this, it is explained (Stephenson 1883, 489) that idiocy is "marked by congenital deficiency of the mental faculties" which "commences with life and continues throughout it". Idiots do not have the power of speech, making only inarticulate noises and "there is no will, but the actions of these beings appear to depend upon impulse, a power of imitation, or mere animal instinct". Stephenson goes on to identify also the state of "imbecility; it is nothing more than idiocy in a minor degree". Imbeciles, unlike idiots, can be trained but "never attain a normal standard of intellect". Although in this text idiocy was still understood as a species of insanity, it is otherwise described in thoroughly Esquirolean terms.

In one sense, then, the 1885 Act constitutes the end of an era, but the concept of consent derived from animal instincts, along with the polarised notion of the sexuality of female idiots, survived the passage of the 1885 Act. Indeed, it did much more than survive. The Mental Deficiency Act 1913 saw the drawing together of three lines of development. The first is that from child to adult. The second is that from idiocy to mental deficiency. Both of these are charted by Foucault. But he does not chart the third, which is that from the singular to the general: from the question of how to respond to isolated sexual encounters involving individual female idiots, to a much broader set of issues, about the state of the nation and the negative effects of a mentally defective and promiscuous class on it. As I will now discuss, from at the 1890s, it became a policy imperative to control the procreation of defectives, whose offspring imposed a burden on the state and threatened its long-term survival, and, ultimately, this entailed state control of the sexuality of female defectives.

\section{The Mental Deficiency Act 1913}

The 1913 Act was the product of a moral panic, clearly in evidence by the 1890 s, with political, economic, social and moral dimensions. It was not, however, a moral panic about idiocy. This was because idiocy was strongly associated with inability to procreate. As Henry Maudsley $(1870,45)$ explained: "Nature puts it [idiocy] under the ban of sterility". Nor was there much panic about imbecility. The reason for this is that, by now, the meaning attributed to this term had altered. A selfappointed "special committee", comprising representatives of all the institutions for idiots, imbeciles and feeble-minded persons, gave unsolicited advice to the Select 
Committee then considering the 1912 Mental Deficiency Bill. In so doing, it noted in passing (Anon 1904, 722) that "the word imbecile in the Idiots Act was intended at the time the Act was passed to cover those who have since become known as the feeble minded". In other words, since Esquirol's specification of the distinction between the two, "imbecility" had been collapsed (back) into "idiocy" in order to free up space for the construction of "feeble-mindedness".

Concerns about idiocy and imbecility were, in fact, noticeably pragmatic. As early as 1886 , Ireland $(1886,182)$ argued that "The asylum is becoming more and more an infirmary, a place for stowing away all the wreckage of our social system, all the flotsam and jetsam of disease and misfortune-a place where is thrown together everything in human nature troublesome and unsightly". Those charged with running prisons had made similar arguments in the 1860s and 1870s, but with little effect (Saunders 1998). The Royal Commission which sat from 1904 to 1908 found little improvement, and this, "far from being some new and startling thing...was merely an authoritative confirmation of the existence of conditions long known to have been in need of attention" (Hyslop 1912, 550). In short, the problem of idiocy and imbecility was constructed at this time partly in humanitarian terms and the need for suitable care, and partly in systemic terms: idiots and imbeciles clogged up institutional facilities designed for insanity, poverty, welfare and punishment. And most of them weren't going anywhere anytime soon. The era of Séguinian optimism had been short-lived. According to evidence given to the 1904 Royal Commission by Charles Caldecott, Medical Superintendent of Earlswood Idiot Asylum, only one per cent of the inmates in his charge were capable of being educated so as to be able to earn a living (Thomson 1998, 13). Most idiots and imbeciles would either never attain the level of instinctive behaviour or never escape it. It is true that instinctive behaviour could be socially problematic. As Maudsley $(1888,161)$ noted in 1888 , it produced "the essential criminal: he is the one who is criminal by reason of defective mental organization. Most often the defect is of the nature of intellectual and moral weakness which, being irremediable, lands the victim in the class of habitual criminals". But by the 1890s, such comments were much more commonly directed at the feeble-minded.

At that time, there was no commonly agreed definition of "feeble-minded", but in 1904 the Royal College of Physicians adopted the following, which was in turn adopted by the Royal Commission which sat from 1904 to 1908, and by the Government, as cl 17(2)(e) of the Bill it introduced in 1912:

Feeble-minded is taken to mean a person who is capable of earning a living under favourable circumstances, but is incapable from mental defect existing from birth or an early age (a) of competing on equal terms with his normal fellows; or (b) of managing himself and his affairs with ordinary prudence (Anon 1904, 1740)

As can be seen, although purportedly a "medical" definition, the terms of reference are economic and social, revealing that the moral panic around feeble-mindedness should not be understood in medical or psychiatric terms, or indeed as a problem of deficiency of care. Rather, this definition articulated middle class anxieties about the state of the nation. It is also, in its positing of the feeble-minded person as male, 
inaccurate and disingenuous. As we shall see, concerns about female defectives were less about the male responsibility, to manage one's affairs with ordinary prudence, than about their procreative potential. In this gendered definition, then, the feminine is paradoxical. Its absence from the text is in sharp contrast to its structuring, sub-textual presence: concerns about mentally defective women were at least as great as those about mentally defective men.

Mark Jackson opens his text on the creation of the category of feeble-mindedness at this time by referring to an editorial published in the British Medical Journal on 1 December 1894, this being entirely typical of a raft of articles that appeared in the medical press in the 1890s. The anonymous author of the editorial does not mince his words: the feeble-minded, to be found in "the borderland of imbecility", between idiots and imbeciles, on the one hand, and the normal, on the other, are "more to be pitied, and certainly are a greater danger to the State, than the absolutely idiotic". This is because such persons are socially inept and unemployable, and in consequence boys become "troublesome", whereas feebleminded "girls become the prey of men, and return again and again to the lying-in wards of the workhouses to become the mothers of imbeciles" (Jackson 2000, 1). Here we can see, first, how the category of imbecility has been collapsed back into idiocy; secondly how concerns about the mentally defective are always already gendered; and thirdly, most immediately relevant, how concerns about the vulnerability of female idiots to sexual exploitation, which had previously been confined to the narrow context of rape law, shift ground altogether, now understood in the context of a perceived need to control the growth in the numbers of mentally deficient persons, and hence female idiot sexuality, in its vulnerability and dangerousness, at a much more general level.

What gave this discourse its political edge was its relation to the twin concepts of degeneracy and hereditary. The 1901 census, which attempted to measure the total number of feeble-minded citizens for the first time, produced a figure of 133,000, which contrasted worryingly with a retrospective 1891 estimate of 97,000 (Thomson 1998, 21). Research commissioned by the 1904 Royal Commission, supervised by Drs A.F. Tredgold and W.A Potts, found 149,628 mental defectives, not including certifiable lunatics (which included idiots) in England and Wales, of whom 66,509 were found to be "urgently in need of provision, either in their own interest or for the public safety" (Darwin et al. 1909, 4). There was little doubt as to the reasons for the continual increase in numbers. In 1911, at a conference organised by the Manchester and Salford Sanitary Association, Tredgold (1911, 7), advised his audience to

Consider for a moment the birth-rate...this has been steadily declining since the year 1876, and it is now the lowest on record...the decline is far from general throughout all classes. It is practically confined to the best elements. It is the steady, persevering, industrious, progressive and capable members...who are having fewer children; whilst the insane, the feeble-minded, the paupers, the criminals, and the whole parasitic class of the country are continuing to propagate with unabashed and unrestricted vigour 
The Committee which oversaw the publication of a 78-page Abstract (Darwin et al. 1909) of the Report of the Royal Commission on the Feeble-Minded (1908) on which in large measure the 1913 Act was based, had similarly described the situation in dystopian terms: "Mental defects are hereditary; the feeble-minded are prolific; and thus the relative amount of feeble-mindedness and insanity increases at an ever-growing rate and threatens the race with progressive deterioration" (Darwin et al. 1909, v).

By the time that Wormald and Wormald produced their commentary on the 1913 Act, they merely reiterated the powerful consensus regarding the feeble-minded which had by then solidified, when they explained $(1913,6)$ that

The law has been hopelessly inadequate to provide for their protection and many of them have ultimately drifted into Institutions or Homes after the hand of crime and debauchery has been heavily laid upon them. Furthermore, by being allowed to repeat their type, the feeble-minded are increasing the ranks of the degenerate and wastrel classes, with disastrous consequences to the entire community.

For the chattering classes, the promiscuous sexuality, and/or the vulnerability, of the feeble-minded threatened the very future of the British race and its empire. And if this was a sexuality grounded in a particular relation to instinct, that relation was also mediated through the opposition between vulnerability and dangerousness. In fact, as can be seen from the passage cited from Wormald and Wormald's text, it was mediated through the deconstruction of that opposition: failure to attend to vulnerability rendered the mentally defective dangerous. In contrast to the way in which the opposition vulnerable/dangerous was constructed in the nineteenth century rape caselaw, which was indeed as an opposition-those below the level of instinct were vulnerable, those acting out of instinct were dangerous-now it functions as a moment of permanent undecidability. By 1895, we find this explicitly recognised by Bourneville (1895, 65, cited in Foucault 2003b, 220), who wrote that the dangerousness inherent in sexuality of a female defective is apparent "at the very moment she was a victim". The 1913 Act legislated this undecidability.

The immediate theoretical underpinning for intervention had been provided by Benedict Auguste Morel, who published his "degeneracy hypothesis" in 1857. Morel (1857) argued that there were various causes of degeneracy, heredity being only one of six possibilities. But it was the hereditary aspect of degeneracy which caught the imagination of British alienists such as Henry Maudsley and, later, of those campaigning for improved provision for the feeble-minded. Morel claimed that once degeneracy had tainted a family, there was little chance of escaping its "law of progressivity". As Ackernecht $(1959,56)$ explains, for Morel, "The first generation of a degenerate family might be merely nervous, the second would tend to be neurotic, the third psychotic, while the fourth consisted of idiots and died out. Because such diseases and diseased families were becoming more frequent, modern society was inevitably approaching extinction".

Maudsley, writing in 1870, did much to introduce these views into the Englishspeaking world, and to combine them with contemporary work on the physical structures of the brain, which had found that the brains of two idiots were "even 
more simple than that of the gibbon, and approach that of the baboon" (Maudsley 1870, 46, citing Marshall 1867). This allowed him to speculate $(1870,47)$ on "a curious and interesting fact, which has by no means yet received the attention it deserves, is that, with the appearance of this type of animal brain in idiocy, there do sometimes appear or reappear remarkable animal traits and instincts". In this sense, Maudsley can be seen to combine the work of Esquirol ${ }^{49}$ with the later work of Morel, articulating a theoretical approach which sees idiocy in terms of degeneracy, and degeneracy in terms of the descent towards and finally beyond the instinctive state. For present purposes, however, the vital point is that instinct theory is not displaced but rather embedded and embellished by the arrival of the degeneracy hypothesis into late nineteenth century debates around idiocy.

By the turn of the century, such ideas were also being presented in terms of the new science of "eugenics" and its inventor Sir Frances Galton. Galton sought to apply the work that his cousin Charles Darwin had been undertaking on evolutionary theory to the improvement of individuals and species. In 1883 he coined the term "eugenics" to describe the science which "especially in the case of man, takes cognisance of all influences that tend in however remote a degree to give the more suitable races or strains of blood a better chance of prevailing speedily over the less suitable than they would otherwise have had" (Galton 1883, 17). Galton's ideas were slow to spread initially, but in the decade after 1901 their acceptance was rapid, and "By 1910...the word, and the concept, had become commonplace... and they were to be encountered wherever the 'social problem' [of the feeble-minded] was treated-in the press, at medical gatherings, in novels, in Church assemblies, and in Parliament" (Barker 1983, 197). The Eugenics Education Society (EES) was formed in 1907, and the Eugenics Review established in 1909. In 1912, the EES hosted the First International Eugenics Conference in London, attended by 750 delegates from across Europe, America, and Australia (Larson 1991, 46). Proceedings were overseen by the president of the EES, Major Leonard Darwin, son of Charles. By then, the EES was a vocal and influential proponent of the 1913 Act.

Galton's eugenics, like degeneracy theory, is better understood as the development rather than the rejection of instinct theory. Galton had very little to say explicitly about mental deficiency, but it is clear that he built on Darwin's theory; and Darwin explicitly incorporated Maudsley's view, themselves as we have seen incorporating an understanding of Esquirol's idiocy-instinct relation, into his work (see Darwin 1872, 245-246). Moreover, discussing criminality and insanity, Galton $(1883,42)$ suggests that

The ideal criminal has marked peculiarities of character; his conscience is deficient, his instincts are vicious, his power of self-control is very weak....The absence of self-control is due to ungovernable temper, to passion, or to mere imbecility, and the conditions that determine the particular description of crime are the character of the instincts and of temptation.

\footnotetext{
${ }^{49}$ Maudsley $(1870,48)$ mentions Esquirol's “instinctive idiot” approvingly.
} 
He had less to say about women, but he did note $(1909,82)$ that "the women commonly become prostitutes", and it is reasonable to suppose that he saw that instinct as the cause of that, just as it was the cause of criminality in men. In short, it is clear that Galton, like Morel, Maudsley and Darwin, is firmly within the tradition traceable back to Esquirol; that idiocy (now mental deficiency) is the manifestation of instinct, unrestrained by social convention.

In the 1913 Act, this thread of instinct theory came together with that which had been articulated around the sexuality of female idiots in the "animal instinct" cases of the previous century, constituting the generalisation of the relation between female idiot sexuality and instinct, and a new disciplinary regime of incarceration aimed at a large swathe of the female (pauper) population. Initially, however, the government's proposals for legislation bore no obvious gendered dimension. A government Bill was introduced in 1912, the result of pressure from the CSO and the EES, which had both introduced their own. ${ }^{50}$ Clause $17(\mathrm{e})$ of the government's Bill provided that defectives liable to institutionalisation should include those women and men "in whose case it is considered desirable in the interests of the community that they should be deprived of the opportunity of procreating children". However, that Bill failed to complete its Parliamentary passage, partly because of concerns that it went too far in proposing preventative detention of mental detectives as a birth control strategy. Clause 17(e) was, in the view of Sir Joshua Wedgewood M.P., who detected a gendered dimension behind its gender-neutral facade, "about the most abominable thing ever suggested. It is directed simply against unfortunate women who have babies and who do not take precautions against having them". 51

Wedgewood was right to be cynical about the apparent gender-neutrality of clause 17(e): as discussed above, "feeble-mindedness" was always already gendered. It was not so much that feeble-mindedness tended to manifest as criminality in men, but rather that the criminality of female defectives was a consequence of their sexual promiscuity. As Bartley $(1999,119)$ has pointed out, "By the late nineteenth century prostitution became more and more associated with the "feeble-minded"". The opening of institutions for feeble-minded girls and young women which occurred at this time was motivated in part by a philanthropic concern, that inability to compete for employment within the legitimate labour market might force feeble-minded women to take up prostitution. But such developments were also motivated for reasons similar to those behind the 1913 Act, that is, to prevent the feeble-minded from breeding. This may have been based on concerns about the economic burden of ever more feeble minded or idiot children, but there was also a more moral and censorious dynamic at play, which reconstituted and redeployed the same vulnerability/dangerousness dynamic which had underpinned the caselaw concerning the alleged rape of female idiots in the middle decades of the nineteenth century. All of these factors come together, for

\footnotetext{
50 The EES drafted the Feeble-minded Persons (Control) Bill and the COS the Mental Defect Bill. The latter was withdrawn almost immediately after but the EES's Bill went to the committee stage before being withdrawn when the Government introduced its own legislation (Hayes Newington 1912).

51 HC Deb 19 July 1912, vol 41 col 711.
} 
example, in evidence given to the Royal Commission by Mary Denby. Denby suggested that "The first test of [mental deficiency] I think is that if a woman comes into the workhouse with an illegitimate child it should be considered evidence of weakness of mind: there is certainly a lack of moral fibre" (Royal Commission 1908, vol 1, 61.). Here, both intellectual and moral weakness, and dangerousness and vulnerability, are conflated, with themselves and with each other, around the axis of sexuality and instinct. As Denby $(1910,7)$ mused a few years later "It is as though, when the higher faculties have dwindled, the lower, or merely animal, predominate in an unusual degree".

The linkage of feeble-mindedness with prostitution, by Denby, by Galton, by W.A. Potts in his evidence to the Royal Commission (Royal Commission, 1908, vol 1, 470), and others, merely writ such concerns large. Prostitution per se, but especially amongst the feeble-minded, manifested the danger of female idiot (now defective) sexuality in terms of vulnerability/danger. The feeble-minded woman was seen as temptress of husbands, corruptor of children, and spreader of disease. When this moral discourse fused with the apparently medical scientific discourse said to demonstrate the rapidity with which the feeble-minded procreated and the high rates of defectiveness in their offspring, the effect, according to Simmons $(1978,394)$, was to create "near hysteria...about the social problem of mentally defective women", both in the Royal Commission hearings and in debates in Parliament concerning the various mental deficiency bills.

In March 1913, the government presented a new Bill, which was to become the 1913 Act. This was seen to be "a much better Bill than its predecessor" (Douglas 1913, 487), meaning that it was sufficiently modified as to satisfy moderates' concerns of a hijack by those following a radical "eugenics" agenda. It was passed by the House of Commons by a majority of 180 to three on 30 July. ${ }^{52}$ Of particular interest here is the replacement for $\mathrm{cl}$ 17(2)(c), which became s 2(1)(b)(vi) of the 1913 Act. This provided that a woman may be institutionalised or made subject to guardianship if "in receipt of poor relief at the time of giving birth to an illegitimate child or when pregnant of such child".

The new provision was seen at the time as a shift from a preventative to a, more moderate, reactive position in relation to the control of the sexuality of the mentally deficient, and as a key example of the removal of "eugenic" ideas from the legislation. The Home Secretary, Reginald McKenna, introducing the 2nd reading debate on the 1913 Bill, claimed that "We have... omitted any reference to what might be regarded as the Eugenic idea... as the measure now stands, it exists for the protection of individual sufferers". ${ }^{53}$ The new law, in other words, was purportedly motivated by philanthropic factors. It was not an attempt at social engineering.

There are two points to be made here. First, it is implausible to suggest that this replacement provision was "for the protection of individual sufferers". The 1913 Act was posited on the need for protection for society from the mentally defective population, and this is what s 2(1)(b)(vi) reflects. There was, for example, no scope for consideration of the best interests of those defective women who came within $s$

\footnotetext{
${ }^{52}$ HC Deb 29 July 1913 vol 56 c 499.

${ }^{53}$ HC Deb 28 May 1913 vol 53 c 221.
} 
2(1)(b)(vi): intervention was based, rather, on an a priori judgement that the public interest justified the prevention of mentally deficient women from further procreation. And clearly, the requirement of "illegitimacy" reveals the moral component in the definition of "defective". Secondly, that s. 2(1)(b)(vi) was seen simply as a moderation of the initial proposal reveals the extent to which, by 1913 , the construction of mentally defective female sexuality, as being contained absolutely within the undecidable opposition of vulnerability and dangerousness, had become part of common sense. In other words, the reason that the new provision achieved consensus and very little criticism is that finally, with s 2(1)(b)(vi), the 1913 Act located its main target: those "feeble-minded women known as the "ins and outs' of the Workhouses" (Wormald and Wormald 1913, 14). It was these women who were seen, by reason of their promiscuity and fecundity, to undermine attempts to improve the lot of the poor and of the nation, and who constituted the core of the problem of mental deficiency.

\section{Concluding Comments: After 1913}

Academic debate around the 1913 Act has revolved around the question of whether it should be seen as "eugenic" or not: that is, whether it was an exercise in social engineering (the control of the dangerous) or philanthropy (the protection of the vulnerable). However, applying the argument I have pursued in this article, it is evident that this is to pose the issue inappropriately. By 1913, the terms of this opposition, which had functioned around two distinct poles in the nineteenth century rape caselaw, had collapsed into each: vulnerability was danger was vulnerability. The relation was now undecidable. As such, proponents of eugenics felt able to support measures claimed as designed to protect vulnerable individuals. Prominent EES member Langdon-Down $(1913,166)$ explained that, despite the alleged removal of the "eugenic idea" from the 1913 Act, "the powers that are desirable in the interests of the individual defective are... similar to those which have been asked for in the interests of the community from a Eugenics point of view". The EES may not have approved of the humanitarian rhetoric that husbanded the 1913 Bill through to Royal Assent, but it approved well enough of the new powers of control thereby enacted.

Much more relevant is the way in which the Act was actually used. The advent of World War One brought severe budgetary restraints. The Board of Control set up under the Act $^{54}$ advised local Mental Deficiency Committees that it would only fund cases in which "the grounds for detention were urgent" (Beds Mental Deficiency Committee 1915 in Walmsley 2000, 66). Nonetheless, by 1915, 71 Institutions and Homes had been licensed under the Act, some of them containing "several hundred inmates" (Kirby 1915, 133). Immediately, as Walmsley (2000) discovered, the Act was used predominantly to control adult women. In her study, albeit involving small numbers, around $60 \%$ of those considered by the Bedfordshire Mental Deficiency Committee were female, and whereas the use of the Act in the case of an adult male

$\overline{{ }^{4} \text { S 21, Mental Deficiency Act } 1913 .}$ 
was rare, half the females before the committee were adults; most were institutionalised by decision of the committee; and in most cases the reason given was concern about inappropriate sexual behaviour (Walmsley 2000, 67). Thomson (1998, 249-252) has reported similar findings when examining the operation of the 1913 Act in its early years in London. Moreover, the Board of Control required local authorities to give special attention to any female mental defective who worked or associated with prostitutes (Board of Control 1914, 51, cited in Thomson 1998, 251). In short, as might be expected given the impetus behind it, the Act in its operation was focussed primarily on containing the sexuality of female adult defectives.

Thomson, discussing the years after 1913, has suggested $(1998,251)$ that this period

need[s] to be placed in the context of a major shift in the anxieties which surrounded female sexuality: a discourse which had constructed women as the weaker, purer sex, who had to be protected against moral vice, began to be overshadowed by a parallel discourse which configured the individual female as a potential danger to the community, a vector for the spread of immorality, disease, and degeneration. In line with such anxieties, the feeble-minded woman, who had originally been an object of pity and protection, was now increasingly thought of as a danger.

Such anxieties were exacerbated by wartime conditions, and the risk of soldiers becoming infected with sexually transmitted disease by feeble-minded women (Walmsley 2000). However, as I have argued, the discourse of dangerousness was far from new in 1913. Rather, the real novelty of the 1913 Act was that it embedded the newly collapsed vulnerability/dangerousness opposition as a moment of permanent undecidability in law, and many women institutionalised under its terms were unable to negotiate a way beyond the paradox of this polarised and yet collapsed opposition, consequently spending many years or even a lifetime in institutional "care".

As such, the 1913 Act should be seen, in my view, not so much as a departure, but rather as a culmination. It marked the generalisation of Esquirol's instinct theory of idiocy as a justification for the control of the sexuality of mental defectives females, albeit that "instinct" was barely discussed in the debates preceding the Act; except tangentially through the discussion of heredity and degeneracy. "Instinct" enters into general currency at this time through "backdoor" means, in the sense that these discourses of heredity and degeneracy were underpinned by instinct: it is the limited capacities of the mentally deficient, to act only on instinct, which are inherited and which, progressively lead to familial and social degeneration. Ironically, the "degeneracy hypothesis" was, by 1913, largely discredited (Ackernecht 1959, 58). But it had performed a vital role for the future development and spread of psychiatric power. It re-established the link between idiocy and lunacy, broken by Esquirol. In this sense, the 1913 Act is a paradox. Just at the moment when idiocy, albeit by now enlarged into the concept of mental deficiency, finally reflects Esquirol's aetiological breakthrough and is rendered distinct from lunacy as a matter of law, the 1913 Act, reflecting degeneracy theory, 
also brings those two concepts back together as causally linked, as merely different stages of degeneracy. This made institutionalisation and psychiatrisation seem appropriate for mental deficiency, as it did for lunacy. And it did so around this grounding concept, the constant explanatory feature, of "instinct".

To this extent, I share Foucault's conclusions, based on developments in this period in France. However, an examination of the history of instinct in England demonstrates that Foucault's analysis begins too late in the day. In England, instinct first enters forensic psychiatry and law, not through controls over idiot children, but through the series of rape cases discussed in the second section of this paper, where it underpins law's construction of the sexuality of female idiots in terms of the danger/vulnerability opposition. And just as "instinct" can be traced through subsequent developments in law and psychiatry, so too can this concern for the unstable sexuality of mentally defective women. One symptom or consequence of the medical, social and political anxieties which coalesced around the problem of the feeble-minded in the decades either side of the turn of the twentieth century, was that the opposition between danger and vulnerability imploded. This in turn provided the makers of social policy and legislation had a ready-made discourse, provided by psychiatry, through which to articulate and justify the need for legalpsychiatric, institutional, control of the dangerous/vulnerable sexuality of mentally deficient women.

\section{Coda: A History of the Present}

My aim, like Foucault, has been to write a "history of the present" and so, albeit that this paper has focussed on the chapter of that history which unfolded between 1846 and 1913, I would like to give some brief indication, by way of closing this article, as to how its historical analysis has a contemporary relevance. It should be noted, in this regard, that the criminal prohibition established by the Criminal Law Amendment Act in 1885, and s 56 of the 1913 Act (which added further offences prohibiting sexual relations involving a mentally defective woman subject to its provisions), were re-enacted, substantively unaltered, as ss 7 and 8, Sexual Offences Act in 1956 (subsequently collapsed into one offence, inserted as s 7 of the 1956 Act by s 127, Mental Health Act 1959). The crime of unlawful sexual intercourse with a mental defective was not repealed until the Sexual Offences Act 2003 came into force on 1 May 2004. The embargo on sexual relations with a dangerous/vulnerable female mental defective, the construction of her sexuality as absolutely other, which, responding to the caselaw discussed in this article, came into being in 1885 , may not pertain in the present, but it was only very recently brought to an end.

The 2003 Act replaced the prohibition on sexual relations involving a female defective with a new raft of offences (in ss 30-44), which attempt to balance the "competing goals in need of reconciliation when issues of mental capacity and consent are considered: the need to respect choices made by those who are mentally disabled, and the need to ensure that such people are protected from abuse and exploitation" (Law Commission 2000, para 4.6). Now, sexual activity involving an intellectually impaired person is only an offence if that person "has a mental 
disorder and...because of it or for a reason related to it...is likely to be unable to refuse" to engage in the activity in question. If such a person has capacity to consent, and does in fact consent, no offence is committed. This position reflects arguments which advocates of disability rights have been making for some considerable time (Shakespeare 2006, especially ch 11; McRuer and Mollow (eds) 2012), that intellectually impaired persons have the same sexual feelings and emotions, and should have the same rights to sexual freedom, that others enjoy.

Following the removal of the absolute prohibition in 2004, the ground shifted. Both the civil and criminal courts have busied themselves in developing a test for capacity to consent to sexual relations. All of this seems positive (if somewhat belated), because it seems to imply that the construction of the sexuality of intellectually impaired women that was undertaken between 1846 and 1913 is irrelevant to the modern law. In 2013, unlike 1913, the law is premised on inclusion not exclusion, on the universality of human rights and freedoms, and is intolerant of discrimination of any description. When one turns to the caselaw, however, one finds judicial statements such as this:

in the context of human sexual relations...choices are generally made rather more by emotional drive and instinct than by rational choice. Of course there is a rational element that has been for most people assimilated into instinct and the control of emotional drive.

This was said by Hedley $\mathrm{J}$ in 2012. ${ }^{55}$ The case concerned $\mathrm{H}$, aged 29, diagnosed as having mild learning difficulties, atypical autism, with an IQ measured at 64, and clearly vulnerable. $\mathrm{H}$ had been sectioned after recounting to a psychiatrist

an extensive, if confused, history of the willingness to have sex with anyone who asked her including strangers. She indicated that she was engaging in sex with multiple partners at the same time, including a group of much older men, considered that she was bi-sexual, and had engaged in oral and anal sex and that she had attempted to have sex with a dog. ${ }^{56}$

Hedley $\mathrm{J}$. found that $\mathrm{H}$ failed to demonstrate capacity to consent to sexual relations "partly through an inability to deploy the knowledge she has when (as readily happened) she was sexually aroused" (para 30). My point is not about whether this case was rightly decided, and I am not concerned here to chart its relationship to the body of jurisprudence to which Hedley J. sought to contribute. Rather, my point is that this case serves as an illustration of the continuing currency of the instinct theory of female defective sexuality and the collapsed opposition between vulnerability and dangerousness. $\mathrm{H}$, like the women who gave consent to sex as the expression of animal instincts in the nineteenth century, like the women who threatened the existence of the nation and its empire in 1913, is seen as both vulnerable and dangerous, as possessed of a dangerous, instinctive sexuality unrestrained by any "rational element": indeed, the strength of her instinct, the

\footnotetext{
55 A Local Authority v $H$ [2012] EWHC 49 (COP).

56 Ibid at para. 9.
} 
extent of her sexual arousal, is precisely what ousts any rationality that $\mathrm{H}$ might possess.

That this case is from 2012 not 1912 demonstrates that the ideas around female idiot sexuality that I have attempted to chart were not abandoned in 1885 , nor in 1913, nor even in 2003. Robert McRuer $(2011,112)$ has recently argued that critical theories of disability, or as he describes it "crip theory", has failed to internalise Deborah A. Stone's (1984) argument that disability can be figured as privilege, the main example being the right to access services otherwise unavailable. On the other hand, for McRuer, such privileging is always capable of being reversed, or of masking discrimination elsewhere (he gives, amongst others, the example of Dutch law providing for the provision of sex workers for disabled persons, sitting alongside the discriminatory assumptions underpinning Dutch policy on assisted suicide, which, he argues, equates "a life not worth living" with "disability"). This seems to me to be the appropriate way, for example, to read developments after 2003: although intellectually impaired people have been "given" legal rights to sexual freedom, provided only that the individual in question has capacity to consent to sexual relations, at the same time the pernicious, dehumanising, discourse of animal instinct has continued to animate legal discourse.

As Margrit Shildrick (2009: 2) has suggested, "Against the standard demands for an extension and solidification of rights for disabled people, and for a more thoroughgoing inclusion of their specific interests in cultural production", there is a need to pursue "an investigation of what it is that continues to impede the evolution of equitable conditions of possibility". My suggestion is that here, what impedes "rights talk", when talked by law, is that it continues to be infused with what might be described as "instinct talk". This is not a point, as McRuer makes, about the pernicious nature of neoliberalism. But it is a point about the pernicious nature of law, and the need to be circumspect when bestowed with the gift of "rights". It is also a point, I would suggest, the full force of which can only be appreciated if it is put in its, particular and problematic, historical context.

Acknowledgments I would like to thank my colleagues Thérèse Murphy, Nell Munro and David Fraser, and the anonymous reviewers for Feminist Legal Studies, for their very helpful comments on earlier drafts of this article. This article is dedicated with love to the memory of Josie, who inspired the research upon which it is based.

Open Access This article is distributed under the terms of the Creative Commons Attribution License which permits any use, distribution, and reproduction in any medium, provided the original author(s) and the source are credited.

\section{References}

Ackernecht, Erwin H. 1959. A short history of psychiatry. London: Hafner.

Anon. 1904. Royal College of Physicians of London. The Lancet 1740 (issue 4242, 17 Dec 1904).

Barker, David. 1983. How to curb the fertility of the unfit: The feeble-minded in Edwardian Britain. Oxford Review of Education 9(3): 197-211.

Bartley, Paula. 1999. Prostitution: Prevention and reform in England, 1860-1914. London: Routledge. 
Bedfordshire Mental Deficiency Committee. 1915. Mental deficiency paper no. 3. 23 Nov 1915.

Board of Control. 1914. 1914 Circular: Memorandum as to grants to voluntary societies. 2 April 1914. Bosanquet, Helen. 1914. Social work in London 1869-1912: History of the Charitable Organisation Society. London: Harvester Press (1973 edition).

Bourneville, D.M. 1895. Assistance, traitment et Education des infants idiots et degeneres. Paris: Alcan. Brady, Cheyne. 1865. The training of idiotic and feeble-minded children. Dublin: Hodges, Smith and Co.

Craft, Anne. 1983. Sexuality and mental retardation: A review of the literature. In Sex education and counselling for mentally handicapped people, ed. Michael Craft, and Anne Craft. Tunbridge Wells: Costello.

Charity Organization Society. 1893. The feeble-minded child and adult. London: Swan Sonnenschein and Co.

Copeland, Ian. 1996. The making of the dull, deficient and backward pupil in British elementary education 1870-1914. British journal of educational studies 44(4): 377-394.

Darwin, Horace et al. (eds.), Mrs Walter Slater (who wrote the text). 1909. The problem of the feebleminded: An abstract of the report of the Royal Commission on the care and control of the feebleminded. London: King and Son.

Darwin, Charles. 1872. The expression of the emotions in man and animals. London: John Murray.

Departmental Committee on Defective and Epileptic Children. 1898. Report of the Departmental Committee on Defective and Epileptic Children. C. 8746.

Denby, Mary. 1901. Feebleness of mind, pauperism and crime. Glasgow: Glasgow Provincial Committee for the Care of the Feeble-Minded.

Denby, Mary. 1910. The problem of the feeble-minded. Manchester 1910, pamphlet.

Douglas, A. R. 1913. Some suggestions respecting the care of the feeble-minded under the mental deficiency bill. British Journal of Psychiatry 59: 487-492.

Doyle, Suzanne. 2010. The notion of consent to sexual activity for persons with mental disabilities. Liverpool Law Review 31: 111-135.

Duncan, P. Martin, and William Millard. 1866. A manual for the classification, education of the feebleminded, imbecile and idiot. London: Longman, Green and Co.

Esquirol, J.E.D. 1845. Mental maladies (trans: Hunt, E.K.). Philadelphia: Lea and Blanchard. First published in French in 1820 as Des Maladies mentales.

Farrall, Lyndsay Andrew. 1985. The origins and growth of the English eugenics movement, 1865-1925. New York: Garland Publishing Co.

Foucault, Michel. 1977. Discipline and punish: The Birth of the prison. London: Allen Lane.

Foucault, Michel. 2003a. Abnormal: Lectures at the College de France 1974-1975 (trans: Burchell, Graham). Verso: London.

Foucault, Michel. 2003b. Psychiatric power: Lectures at the College de France 1973-1974, ed. Jacques LaGrande (trans: Burchell, Graham). Basingstoke: Macmillan.

Frieden, Michael. 1979. Eugenics and progressive thought: A study of ideological affinity. Historical Journal 22: 645-671.

Galton, Francis. 1883. Inquiries into human faculty and its development. London: Macmillan.

Gladstone, David. 1996. The changing dynamic of institutional care: The western counties idiot asylum 1864-1914. In From idiocy to mental deficiency: historical perspectives on people with learning disabilities, ed. David Wright, and Anne Digby, 134-160. London: Routledge.

Hayes Newington, H. 1912. Legislation for the feeble-minded. Journal of Mental Science 58: 637-657.

Hyslop, Theo B. 1912. The Mental Deficiency Bill, 1912: A discussion on the legislative proposals for the care and control of the mentally defective, opened by Dr. Theo Hyslop at the annual meeting of the medico-psychological association held at Gloucester on July 12th 1912. Journal of Mental Science 58: 548-597.

Ireland, William W. 1886. On the admission of idiotic and imbecile children into lunatic asylums. Journal of Mental Science 32: 182-193.

Jackson, Mark. 2000. The borderland of imbecility: Medicine, society and the fabrication of the feeble minded in late Victorian and Edwardian England. Manchester: Manchester University Press.

Jones, Kathleen. 1972. A history of the mental health services. London: Routledge and Kegan Paul.

Kelves, Daniel J. 1985. In the name of eugenics: Genetics and the uses of human heredity. Berkeley and Los Angeles: University of California Press.

Kirby, Anna. 1915. Notes on the present working of the Mental Deficiency Act, 1913. Eugenics Review 7(2): 133-135.

Langdon-Down, Reginald. 1913. The mental deficiency bill. Eugenics Review 5(2): 166-167. 
Larson, Edward J. 1991. The rhetoric of eugenics: Expert authority and the mental deficiency bill. The British Journal for the History of Science 24(1): 45-60.

Law Commission. 2000. Consent in sex offences: A report to the home office sex offences review. London: Home Office.

Marshall, John. 1867. Outlines of physiology, human and comparative. London: Longman, Greens and Co.

Maudsley, Henry. 1870. Body and mind: an inquiry into their connection and mutual influence, specially in reference to mental disorders; being the Gulstonian lectures for 1870, delivered before the Royal College of Physicians. London: Macmillan and Co.

Maudsley, Henry. 1888. Remarks on crime and criminals. Journal of Medical Science 34: 159-167.

McCarthy, Michelle. 1999. Sexuality and women with learning disabilities. London: Jessica Kingsley.

McRuer, Robert. 2011. Disabling sex: Notes for a crip theory of sexuality. GLQ: A Journal of Lesbian and Gay Studies 17(1): 107-117.

McRuer, Robert, and Anna Mollow (eds.). 2012. Sex and disability. Durham, NC: Duke University Press.

Mead, Frederick, and A.H. Bodkin. 1885. The criminal law amendment act 1885 with introduction, notes and comment. London: Shaw and Sons.

Morel, Benedict Augustin. 1857. Traité des dégénérescences physiques, intellectuelles et morales de l'espèce humaine et des causes qui produisent ces variétés maladives. Paris: J.B. Baillière.

Morrison, Wayne (ed.). 2001. Blackstone's commentaries on the laws of England (1793, 9th ed.). London: Cavendish.

Oliver, Michael, and Colin Barnes. 2012. The new politics of disablement. London: Palgrave Macmillan.

Potts, Patricia. 1983. Medicine, morals and mental deficiency: The contribution of doctors to the development of special education in England. Oxford Review of Education 9(3): 181-196.

Royal Commission on the Blind, the Deaf, and the Dumb. 1889. Report of the Royal Commission on the Blind, the Deaf, and the Dumb. C 5781. London: HMSO.

Royal Commission on the Care and Control of the Feeble-Minded. 1908. Report of the Royal Commission on the Care and Control of the Feeble-Minded, vol. 1-7 Cd 4215-4221, vol. 8 Cd 4202. London: HMSO.

Saunders, Janet. 1998. Quarantining the weak-minded: Psychiatric definitions of degeneracy and the lateVictorian asylum. In The anatomy of madness: Essays in the history of psychiatry, ed. W.F. Bynum, et al., 273-296. London: Routledge.

Schenk, F., and A.S. Parles. 1968. The activities of the Eugenics Society. Eugenics Review 60(3): $142-161$.

Séguin, Edouard. 1842. Théorie practique de l'éducation des enfants arriérés et idiots. Paris: GermerBaillière.

Séguin, Edouard. 1846. Traitement moral, hygiène et éducation des idiots. Paris: Baillière.

Shakespeare, Tom. 2006. Disability rights and wrongs. London: Routledge.

Shildrick, Margrit. 2009. Dangerous discourses of disability, subjectivity and sexuality. London: Palgrave Macmillan.

Simmons, Harvey G. 1978. Explaining social policy: The English Mental Deficiency Act of 1913. Journal of Social History 11(3): 387-403.

Stephenson, T. 1883. Taylor's medical jurisprudence, 3rd ed. London: J. and A. Churchill.

Thomson, Matthew. 1998. The problem of mental deficiency: Eugenics, democracy and social policy in Britain c.1870-1959. Oxford: Clarendon Press.

Tredgold, Arthur F. 1911. The problem of the feeble-minded. In Proceedings of a conference on the care of the feeble-minded. Manchester and Salford Sanitary Association. London: Sherratt and Hughes.

Unsworth, Clive. 1993. Law and lunacy in pychiatry's "golden age". OJLS 13: 479-507.

Walmsley, Jan. 2000. Women and the Mental Deficiency Act of 1913: Citizenship, sexuality and regulation. British Journal of Learning Disabilities 28: 65-70.

Wormald, John and Samuel Wormald. 1913. A guide to the Mental Deficiency Act, 1913. London: King and Son (reprinted by Gale: Farmington Hills, Michigan, 2010).

Wright, David. 1996. "Childlike in his innocence": Lay attitudes to "idiots" and "imbeciles" in Victorian England. In From idiocy to mental deficiency: Historical perspectives on people with learning disabilities, ed. David Wright and Anne Digby, 118-133. London: Routledge. 